\title{
Geochemical Siliceous and Silicified Facies of Phosphate Series of Ouled Abdoun Basin (Morocco)
}

\author{
H. El Haddi*, A. Benbouziane, M. Mouflih \\ Laboratory of Dynamics Sedimentary Basins and Geological Correlation, Faculty of Sciences Ben M'sik, Hassan \\ II Mohammedia-Casablanca University, Casablanca, Morocco \\ Email: ${ }^{\text {hamid.elhaddi@univh2m.ac.ma }}$
}

Received 22 April 2014; revised 20 May 2014; accepted 17 June 2014

Copyright @ 2014 by authors and Scientific Research Publishing Inc.

This work is licensed under the Creative Commons Attribution International License (CC BY). http://creativecommons.org/licenses/by/4.0/

c) (i) Open Access

\begin{abstract}
Syn-sedimentary post-diagenetic phenomena are remarkable in Moroccan phosphates. Indeed they are reference deposits for geological study, where important interests are given of determination and identification of these geochemical phenomena. Silicification is one of the phenomena that we have studied to determine the diagenetic processes that control the new-formation of silica in phosphate series of Ouled Abdoun. This study was performed on deposit EL Halassa, which belongs to the Ouled Abdoun Basin; they spread out the Maastrichtian to Lutetian. At first, petrographic approach was applied on different terms composing the phosphate series. In a second step, a geochemical approach on the same silica and silicified facies of phosphate series Ouled Abdoun Basin for characterizing silicification deduced the probable links between this diagenetic phenomenon and facies and forms' affect. Ten major trace elements were measured. According to the phases' petrographic relationship, the results were presented and discussed: silicate phase, the carbonate phase and clay phase.
\end{abstract}

\section{Keywords}

Phosphates, Diagenesis, Silicification, Ouled Abdoun, Morocco

\section{Introduction}

The late Cretaceous early Eocene phosphate series at the western coast of Morocco have drawn attention of many scientists for a long time due to its extreme fossil richness. Beside paleontology several investigations

${ }^{*}$ Corresponding author. 
were focused on phosphorite formation, sedimentology and also diagenetic phenomena like silicification. The phosphorite deposited on the wide continental shelf [1]-[7] with facies was controlled by eustatic sea level changes and low subsidence [6] [8]-[10].

The phosphates are one of the few industrial minerals that have no competition from other compounds [11][13]. The phosphorite layers were intensively studied by sedimentological and geochemical means [14] [15]. Moreover, many researches have been done on silicification but not in details [16] [17].

Current studies are focused on the Ouled Abdoun Basin, the largest phosphate basin from Morocco, where the silicification with siliceous forms and silicified facies often occur. Here we studied the phenomena of silicification in order to determine and describe the diagenetic processes that control the transformation of silica in the phosphate series. Besides general petrographic and mineralogical characterizations, geochemical analysis completes the investigation of the different siliceous units and silicified facies.

\section{Geological Setting}

The Ouled Abdoun phosphate basin covers an area of more than $10,000 \mathrm{~km}^{2}$, is located in the structural zone of the Western Meseta of Morocco (Figure 1(a)). The phosphate sequence extends from the Late Cretaceous to the Eocene, with at least thirteen phosphate localities: Khouribga, SidiDaoui, Meraâ EL Arech, Mrizig, Sidi Hajjaj, Sidi Chennane, Ouled Farès, Al Brouj, Ouled Smain, El Halassa, Ghar Tajer, Sidi El Maâti and Kasbat Tadla. Our study is focused on the EL Halassa areain south-southeast part of the basin.

The stratigraphy of the Moroccan phosphate series is based on the selachian biozonation of [1] and [18], which was reviewed and refined by [7]. Recently the chemostratigraphic results realized by [19] and [20] which are remarkably consistent with available biostratigraphicdata based on selachian assemblages. In which they were able to located Selandian-early Thanetian, early-middle Ypresian, middle Ypresian in the uppermost phosphorite horizons and support for absence of the Lutetian in upper part of the Ouled Abdoun phosphate series. These biozonations are the base of the stratigraphic scale of the Moroccan phosphate sequence. In the OuledAbdoun basin, marine sedimentary series includes the following succession: Maastrichtian-Ypresian phosphate sequence that also contain carbonates (marl and limestone) and clay, and Lutetianchert sequence marked by Thersites bank (Hemithersitea, Thersitea) on the top of the sequence. Neogene continental deposits locally cover the phosphate series and/or the Lutetian siliceous sediments.

The studied phosphate series contain a succession of phosphatic levels interbedded by carbonate, siliceous facies and clay (Figure 1(b)). The most important levels from the bottom the top are:

1) Maastrichtian: 8 to 10 meters, contains phosphorites with sandy texture rich in bone debris (bone bed), it is often graded on marl and clay interbedded with phosphate limestone. The lenticular flint marks it.

2) Danian-Selandian-Thanetian: 8 meters of sandy and marly phosphate interbedded with siliceous marls. Danianpart is marked by the absence of marl and clay levels and by a reshuffle in the top of the phosphate levels. Calcified phosphate marks this unconformity surface rich with internal molds of Cardita Coquandi. This sequence lack completely siliceous units.

3) Ypresian: 12 meters of alternating phosphate sequences with: yellow and gray coprolitic sandy phosphates containing shark teeth, white to gray coprolitic phosphatic limestone and white and green marly limestones containing coprolites, finally green and brown compacted clay marl with flint. This sequence is marked by development of various siliceous facies and indication of silicification.

4) Lutetian: 10 meters of alternating siliceous and calcitic plastic marl and marly limestone, with presence of continuous silicified bank and lenticular flint, thin horizons of silicified phosphate and limestone, the whole seriesis covered by dolomitic and siliceous limestone of Thersites.

\section{Materials and Methods}

\subsection{Materials}

A steel hammer for sampling and Hydrochloric acid ( $\mathrm{HCl})$ for tested the carbonates in-situ of outcrops, polythene bags for conserved samples. In laboratory mortars a steel, porcelain and agate for crushed the samples, ICP-OES Atomic Absorption Spectrophotometer ULTIMA 2 JOBIN-YVON for geochemical analysis.

\subsection{Procedure}

Fieldwork and sampling were carried out for the siliceous and silicified facies with a regular mesh of 50 centi- 


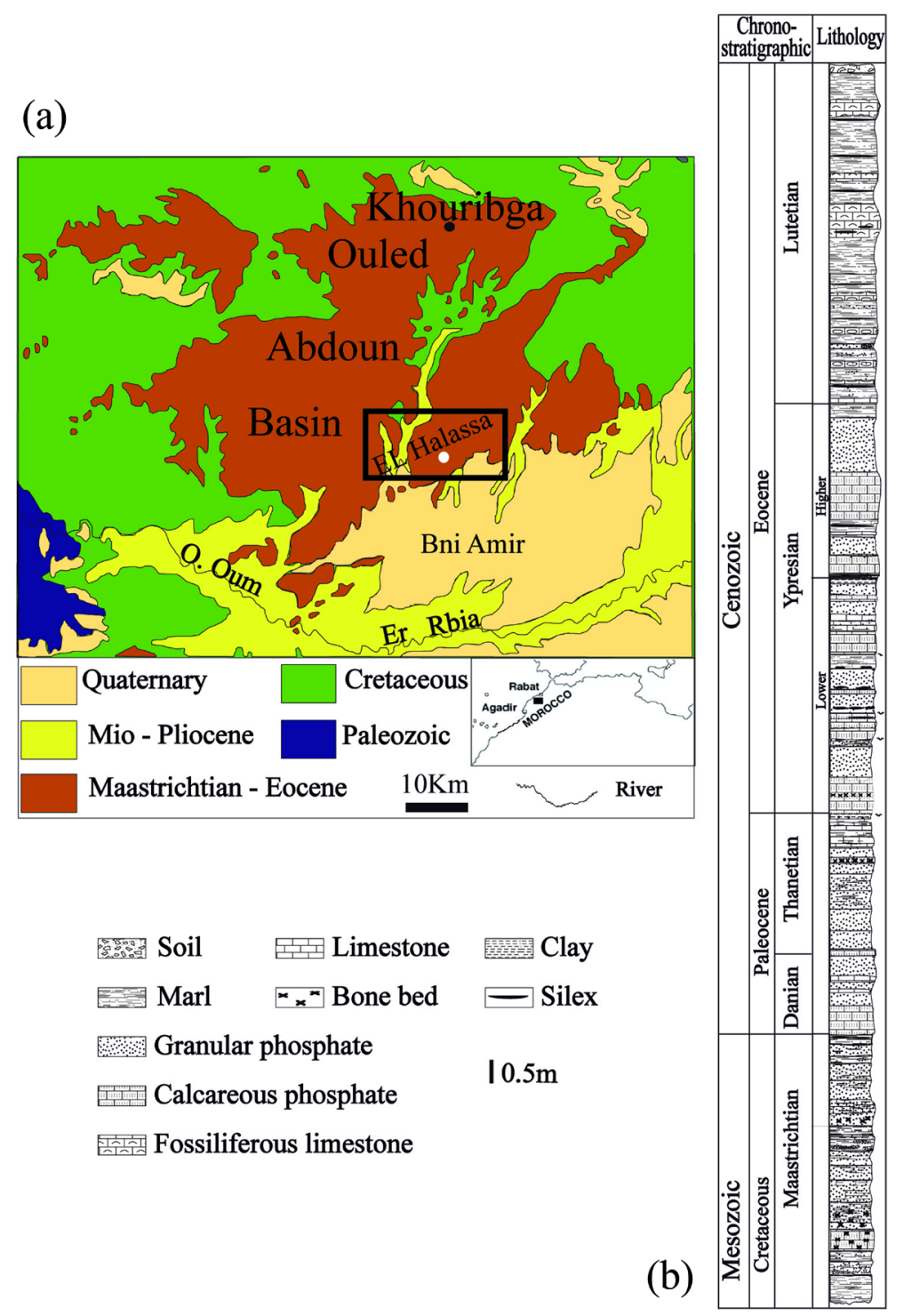

Figure 1. (a) Geological map of the Ouled Abdoun Basin with the sampling sites of EL Halassa. (b) Stratigraphic section of the Ouled Abdoun Basin.

metres and each change of facies especially at the siliceous forms, in the Ouled Abdoun Basin of EL Halassa deposits.

The samples are crushed in a steel mortar to a coarser fraction, and then crushed in porcelain mortar until it became fine grained. The product is powdered up to mesh sizes suitable in an agate mortar, which was then conserved and transferred into polythene bags; they are numbered and packed properly for geochemical analysis.

\subsection{Analyze methods}

The analytical methodologies for this study are the description and analysis outcrops for detected and determined the various forms of silicification. From this description was carried a stratigraphic column. This work was combined with microscopic observations in laboratory for analyzed and interpreted textures of siliceous microfacies and forms of silicification. Major ( $\mathrm{Si}, \mathrm{Al}, \mathrm{Ca}, \mathrm{Mg}, \mathrm{P}, \mathrm{Fe}, \mathrm{K}$ and $\mathrm{Na}$ ) and trace ( $\mathrm{Sr}, \mathrm{Cu}, \mathrm{Cd}$, and $\mathrm{Mn}$ ) elements were analyzed by ICP-OES whose objective is to determine the chemical composition and the relationships between these elements of these facies and silicificaton. 


\section{Results and Discussion}

\subsection{Facies Classification}

The samples analyzed are classified into three facies groups: carbonate, phosphate and silicate facies based on the triangular diagram (Figure 2) of Ca, P and Si content. The samples show large variance, with dominance of the carbonate phase but it is clear that, the facies at EL Halassa also have various content of silica.

\subsection{Macroscopic and Microscopic Observations}

\subsubsection{Silicification of Phosphate Units (Figure 3)}

Silicification of phosphate appears in the Ypresian layers by silicified phosphate of nodular form with centimetric to decametric in size. In some places, it is characterized by continuous bank or flint nodule called nougat facies. These nodules have a texture similar to the texture of the phosphates.

Phosphates flint present in all levels of the studied series of El Halassa area, rich in coprolites that not silicified, most often continuous in space with a centimetric diameter.

\subsubsection{Silicification of Marl Units (Figure 4)}

Silicification of marl is manifested from the Maastrichtian in white marl by brown lenticular flint form centimetric to decimeter with a zonation from center to periphery.

In the Ypresian the silicification occurs as ménilite flint which is a very apparent lithological marker to define the first phosphate layer exploited in Ouled Abdoun Basin. This silicification is present as brown nodules and spherical ellipsoids centimetric surrounded by concretion of whitish marl.

In the Lutetian the silicification is manifested by flint and marl epigenesis formed the complex of alternation siliceous marl, clay and large flint nodules forming the layer called Boujniba roof.

\subsubsection{Silicification of Calcareous Units (Figure 5)}

Silicification of calcareous levels is manifested by partially silicified limestone in Maastrichtian. The Ypresianis characterized by centimeter to decimeter continuous bench and by silicified limestone rich in fossil (Thersitées) in Lutetian. In this unit, the silica is presented by reddish chalcedony called carnelian.

\subsection{Geochemical Analysis}

The use of ICP-OES Atomic Absorption Spectrophotometer makes dosing of major and trace elements, our re-

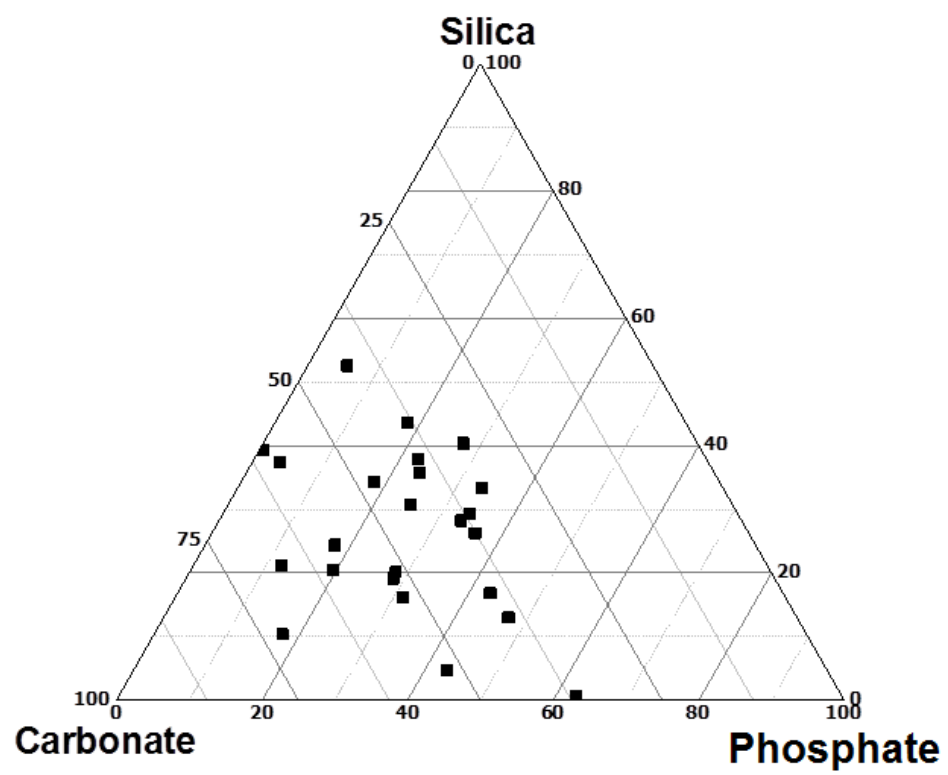

Figure 2. Triangular diagram Silica-Carbonate-Phosphate of samples analyzed. 


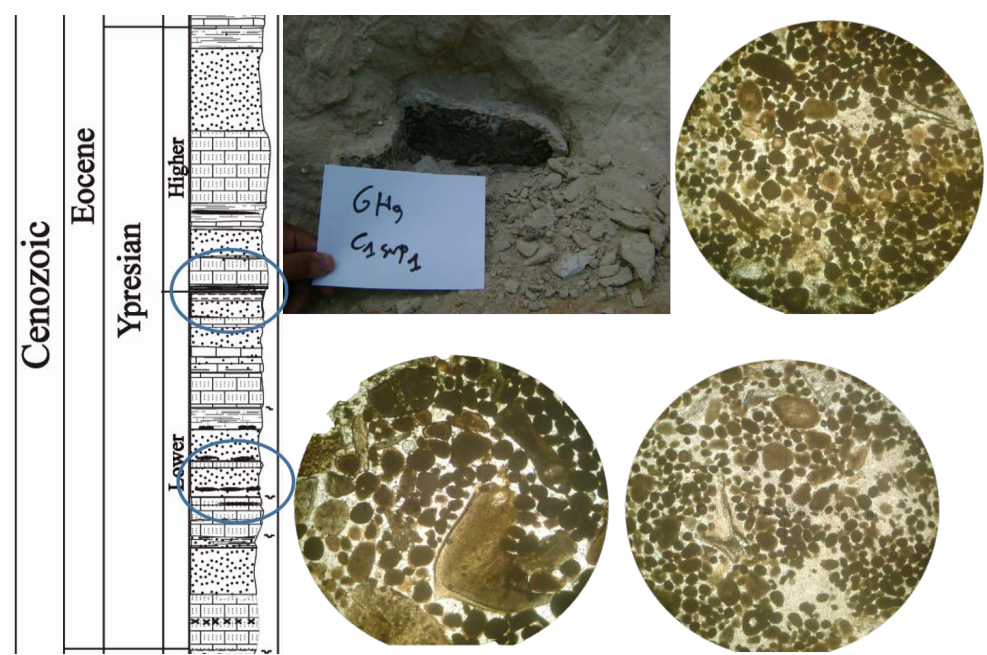

Figure 3. Texture of siliceous microfacies and forms of silicification of phosphate units of EL Halassa in Ouled Abdoun Basin.

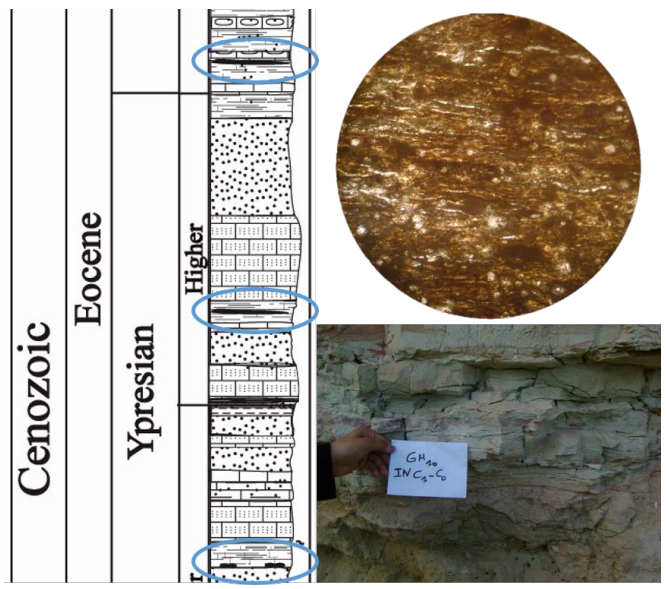

Figure 4. Texture of siliceous microfacies and forms of silicification of marl units of EL Halassa in Ouled Abdoun Basin.

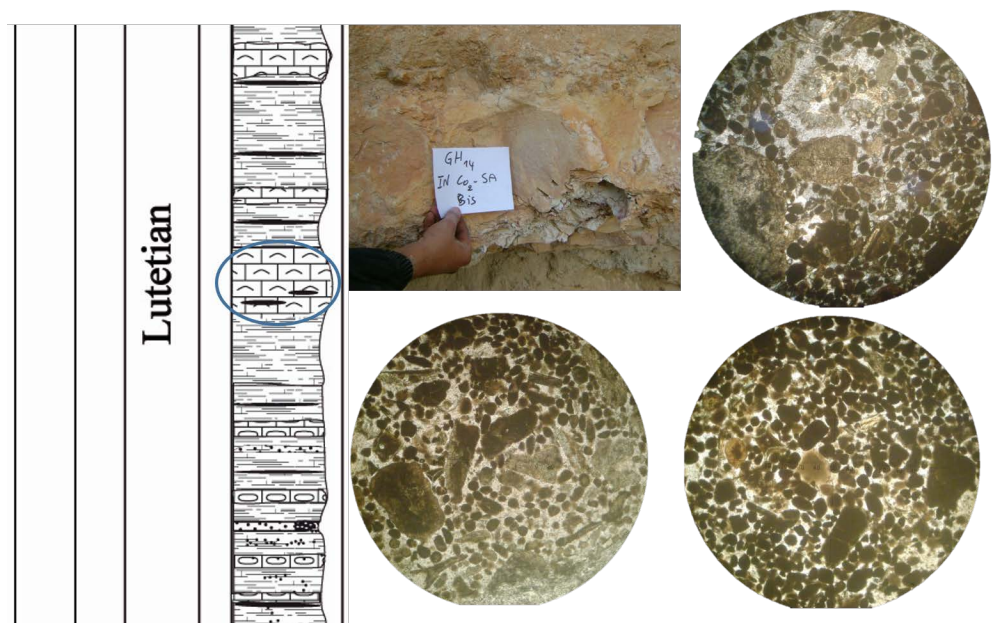

Figure 5. Texture of siliceous microfacies and forms of silicification of calcareous unitof EL Halassa in Ouled Abdoun Basin.. 
sults were completed to those published and, more particularly, those of the mineralogy [21] for silicified faciesin the Ouled Abdoun Basin. Based on the classification made on silicified facies we present geochemical results into two categories a unit related to phosphate and other non-phosphate (Table 1).

The first category that relates to phosphate unit show various content of Silica Si: $0.15 \%$ to $12.72 \%$, Phosphorus P: $4.93 \%$ to $29.27 \%$, Carbonates Ca: $5.35 \%$ to $34.77 \%$ and $\mathrm{Mg}: 0.07 \%$ to $0.51 \%$ and low proportion of $\mathrm{Al}, \mathrm{Fe}, \mathrm{K}$ and $\mathrm{Na}$ whose percentages do not exceed $2.6 \%$.

The contents of trace elements are as follows: Sr: 510.44 to $825.47 \mathrm{mg} / \mathrm{kg}, \mathrm{Cu}: 15.3$ to $32.33 \mathrm{mg} / \mathrm{kg}, \mathrm{Mn}: 6.24$ to $14,84 \mathrm{mg} / \mathrm{kg}$ and Cd: 2.73 to $22.12 \mathrm{mg} / \mathrm{kg}$.

The second category related tonon-phosphate units show that the silica Si varies between $0.08 \%$ to $70 \%$, P between $0.09 \%$ to $41.85 \%$, Carbonates for Ca between $0.91 \%$ to $95 \%$ and for $\mathrm{Mg}$ from $0.09 \%$ to $37 \%$, indicating the presence of dolomite. As for the elements $\mathrm{Al}, \mathrm{Fe}, \mathrm{K}$ and $\mathrm{Na}$ the percentages do not exceed $5.93 \%$, with a singularity of one sample that show high percentages can reach $25 \%$ of aluminium.

Table 1. Major and trace element concentrations for siliceous and silicified samples from the EL Halassa area of Ouled Abdoun Basin.

\begin{tabular}{|c|c|c|c|c|c|c|c|c|c|c|c|c|}
\hline \multirow{2}{*}{ Samples } & \multicolumn{8}{|c|}{ Major elements } & \multicolumn{4}{|c|}{ Trace elements } \\
\hline & $\mathrm{Si}$ & $\mathrm{Al}$ & $\mathrm{Ca}$ & $\mathrm{Fe}$ & K & $\mathrm{Mg}$ & $\mathrm{Na}$ & $\mathrm{P}$ & Cd & $\mathrm{Cu}$ & $\mathrm{Mn}$ & $\mathrm{Sr}$ \\
\hline 1 & 12.72 & 2.12 & 34.77 & 0.99 & 0.18 & 0.49 & 2.60 & 18.89 & 6.52 & 30.02 & 9.40 & 710.21 \\
\hline 2 & 13.66 & 2.12 & 40.11 & 0.81 & 0.14 & 0.31 & 2.00 & 12.98 & 82.53 & 19.61 & 8.40 & 485.06 \\
\hline 3 & 12.19 & 2.09 & 31.16 & 0.43 & 0.57 & 0.51 & 2.56 & 17.15 & 22.12 & 25.33 & 6.24 & 825.47 \\
\hline 4 & 22.58 & 2.54 & 53.55 & 0.64 & 0.12 & 0.40 & 2.48 & 16.50 & 145.87 & 21.81 & 8.60 & 402.52 \\
\hline 5 & 38.90 & 5.93 & 122.95 & 0.58 & 0.30 & 1.02 & 3.31 & 22.35 & 42.73 & 17.58 & 8.97 & 297.09 \\
\hline 6 & 0.15 & 0.08 & 8.44 & 0.09 & 0.14 & 0.15 & 0.27 & 14.47 & 4.07 & 27.06 & 7.11 & 535.04 \\
\hline 7 & 4.24 & 0.13 & 5.35 & 0.14 & 0.14 & 0.07 & 0.29 & 4.93 & 7.24 & 15.30 & 8.19 & 619.43 \\
\hline 8 & 6.20 & 0.18 & 8.47 & 0.24 & 0.07 & 0.08 & 0.54 & 7.30 & 6.98 & 15.62 & 7.14 & 643.52 \\
\hline 9 & 8.03 & 1.27 & 24.50 & 0.33 & 0.17 & 0.20 & 1.58 & 29.27 & 2.73 & 32.33 & 14.68 & 510.44 \\
\hline 10 & 1.16 & 1.58 & 8.07 & 1.11 & 0.38 & 0.73 & 0.09 & 1.98 & 13.28 & 29.46 & 79.24 & 124.48 \\
\hline 11 & 70.03 & 25.63 & 73.12 & 24.88 & 5.46 & 44.27 & 6.87 & 41.85 & 5.83 & 52.46 & 79.97 & 214.24 \\
\hline 12 & 4.03 & 0.51 & 9.65 & 0.53 & 0.53 & 0.25 & 0.56 & 10.30 & 27.21 & 26.59 & 15.48 & 304.50 \\
\hline 13 & 1.29 & 3.49 & 4.21 & 3.61 & 0.54 & 2.64 & 0.13 & 2.50 & 3.17 & 76.83 & 105.92 & 191.64 \\
\hline 14 & 5.29 & 0.70 & 8.11 & 0.43 & 0.13 & 10.17 & 0.84 & 0.09 & 17.56 & 14.35 & 48.85 & 71.38 \\
\hline 15 & 8.74 & 0.59 & 12.56 & 0.24 & 0.12 & 0.27 & 0.61 & 7.11 & 4.61 & 15.04 & 14.56 & 513.40 \\
\hline 16 & 6.39 & 0.36 & 8.87 & 0.40 & 0.07 & 0.23 & 0.45 & 3.40 & 3.61 & 11.10 & 18.20 & 108.79 \\
\hline 17 & 8.75 & 0.51 & 9.88 & 0.37 & 0.11 & 2.46 & 0.45 & 5.82 & 4.63 & 10.45 & 29.30 & 382.14 \\
\hline 18 & 5.99 & 0.75 & 5.24 & 1.16 & 0.16 & 4.09 & 0.37 & 2.51 & 9.48 & 24.06 & 35.45 & 136.75 \\
\hline 19 & 3.95 & 1.08 & 3.15 & 0.71 & 0.31 & 3.39 & 0.38 & 0.41 & 13.72 & 19.26 & 80.83 & 53.83 \\
\hline 20 & 9.00 & 0.73 & 7.17 & 0.30 & 0.12 & 0.26 & 0.57 & 6.13 & 22.87 & 36.16 & 25.85 & 582.74 \\
\hline 21 & 6.07 & 1.33 & 9.55 & 1.24 & 0.32 & 0.65 & 0.51 & 0.60 & 148.36 & 20.90 & 41.19 & 45.64 \\
\hline 22 & 1.40 & 0.22 & 2.00 & 0.54 & 0.06 & 0.09 & 0.12 & 1.93 & 1.31 & 35.27 & 109.78 & 114.69 \\
\hline 23 & 0.08 & 0.29 & 0.91 & 0.36 & 0.08 & 0.14 & 0.06 & 0.75 & 0.49 & 15.74 & 56.20 & 73.66 \\
\hline 24 & 8.15 & 0.23 & 8.12 & 0.78 & 0.05 & 0.09 & 0.50 & 8.19 & 9.18 & 30.17 & 14.84 & 625.69 \\
\hline
\end{tabular}


For trace elements, values are as follows: Sr: 45.64 to $513.4 \mathrm{mg} / \mathrm{kg}$, Cu: 10.45 to $76.83 \mathrm{mg} / \mathrm{kg}, \mathrm{Mn}: 8.4$ to 109 , $78 \mathrm{mg} / \mathrm{kg}$ and Cd: 1.31 to $148.36 \mathrm{mg} / \mathrm{kg}$.

The samples analyzed are part of cloud limited by maximum values about $60 \%$ of $\mathrm{Ca}, 30 \%$ of $\mathrm{P}, 6 \%$ of $\mathrm{Al}$ and $4 \%$ of Na. These four elements show strong positive correlations successively $0.66,0.64,0.84$ and 0.89 , which indicate that these elements are associated with the silicate phase, the proportions in the samples ranged from $10 \%$ to $40 \%$ according to the results of the triangular Silica-Carbonate-Apatite.

The concentrations of Mg, $\mathrm{K}$ and Fe are lower and most often at the limit of detection. Analysis show low correlation of these components with $\mathrm{Si}$, these correlations indicate that the silica does not replace with dolomite in these samples.

Geochemical characteristics identified at the base of the study of silica and silicified facies of phosphate series Ouled Abdoun Basin, show that this series has not suffered large geochemical change during diagenesis. It is remarkable for the low value of oxides of aluminium, iron and trace elements such as cadmium for silicified phosphate terms.

The high content of strontium is similar to the more open marine area and additional strontium can be substituted for the Tardi-diagenetic stage during the silicification from biological silica.

The petrographic and mineralogical study shows that the silica in the siliceous and silicified samples of Ouled Abdoun Basin [21], is presented by amorphous and crystalline form Quartz, Opal (A, C, T and CT). The origin of this silica was attributed to the organisms testing dissolution that populated the basin at the time, through to the contribution of upwelling currents that favored the proliferation of these organisms (sponges and radiolarians).

The formation of the opal is favored by pore water rich in silica, opal mark the early diagenetic stage, the same results were proposed by [22] in the study of the diagenetic evolution of phosphates Bouabout of deposit Meskala.

\section{Conclusions}

The silicification associated with limestones is a little difficult to interprete, because of the contrast between the conditions of solubility of carbonates and silica. This opposition promotes the mutual replacement and erases primary structures.

Petrographic observations of the siliceous and silicified samples from the Ouled Abdoun Basin have revealed that phosphatic grains described are fragments of phosphatic mudstone intact and partially silicified because they sometimes contain bone fragments and silicified coprolite. The absence of concentric structure within the phosphatic mud clasts and the absence of phosphatic cements in the phosphorites also support the reworked origin of the phosphatic grains and presence of border silicification around phosphatic grains, which is of early silicification. The presence of bone fragments into some silicified phosphate and filling silicified phosphate in bone cavities that is comparable to the matrix of the silicified phosphate and siliceous mudclasts suggests that the bioclasts are also of reworked origin and derived from similar phosphatic mudstones rich at silica.

In general, the microscopic observation shows that the phosphatic grains, coprolites and skeletal fragments are silicified partially or totally and the cavities are filled by microcrystalline quartz indicating diagenetic silicification.

Chemical elements associated to silicified phosphatic units and non-phosphatic units show three trends.

A positive trend is marked by high contents of $\mathrm{Sr}$, and low contents of $\mathrm{Al}, \mathrm{Fe}, \mathrm{K}$ and $\mathrm{Na}$, reflecting early diagenetic phase with the rate of organic matter indicated by the mean contents of $\mathrm{Mn}$ and $\mathrm{Cu}$.

A negative trend is marked by low contents of $\mathrm{Sr}$ and higher contents of $\mathrm{Cu}$ and $\mathrm{Mn}$, which characterizes continental influences during the declining of paleoenvironmental water.

A neutral trend is marked by the average contents of $\mathrm{Sr}$ and medium for $\mathrm{Cu}$ and $\mathrm{Mn}$. These characteristics are remarkable at the beginning of depositional sequences.

\section{References}

[1] Arambourg, C. (1952) Les vertébrésfossiles des gisements de phosphates (MarocAlgérieTunisie). Service Géologique du Maroc. Notes et Mémoire, 92, 44.

[2] Wadjinny, A. (1979) Milieu de sédimentation et mécanismes de dépôt des “couches inférieures” de la sériephosphatée de Ben Guerir (Ganntour, Maroc), uneétudeséquentielle. Thèse 3e cycles, Strasbourg, 100. 
[3] Belfkira, O. (1980) Evolution sédimentologiquesetgéochimiques de la sériephosphatée du Maactrichtien des Ouled Abdoun (Maroc). Thèse Doct., Université de Grenoble, Grenoble, 164.

[4] Soncini, M.J. (1992) Three New Dinoflagellate Cysts from the Moroccan Paleocene-Eocene Phosphates. Review of Palaeobotany and Palynology, 70, 325-338. http://dx.doi.org/10.1016/0034-6667(92)90070-W

[5] Noubhani, A. and Cappetta, H. (1992) Evolution de la tailleet de la morphologie des dents dansdeuxlignées de sélaciens: Application biostratigraphique. Journal Tertiary Research, 14, 118.

[6] Moutaouakil, D. and Giresse, P. (1993) Pétrologieetenvironnementsédimentaires des phosphates méso-cénozoïques du bassin des Oulad Abdoun (Maroc). Bulletin de la Societe Geologique de France, 164, 473-491.

[7] Noubhani, A. and Cappetta, H. (1995) Batoïdes nouveaux oupeuconnus (Neoselachii: Rajiformes, Myliobatiformes) des phosphates maastrichtiensetpaléocènes du Maroc. In Elasmobranches et Stratigraphie, Belg. Geol. Surv., Prof. Papers, 278: $157183,7$.

[8] Moutaouakil, D. (1990) Sédimentologieet Minéralisation des Phosphates Ceno Mésozoïque du Sud du Bassin des Ouled Abdoun (Maroc); Application à la Géochimie de L’Uranium. Soutenue à Perpigna.

[9] Mouflih, M. (1991) La sériephosphatée du gisement de Benguerirséquences de faciès, évolutionséquentielle, minéralogieetgéochimie (Maastrichtien-lutétien). Thèse de 3ème cycles, Université Cadi Ayyad, Marrakech, 34-55.

[10] Mouflih, M., Chellai, E.H., Pascal, A. and Et Lang, J. (1994) Origine de la minéralisation des constituantspétrographiques des phosphates et grains du gisement de Benguerir (Maroc). 12ème coll. des bassinssédimentaires Marocains, Casablanca, 33.

[11] Savornin, J. (1921) Sur la répartitionetl'allure des bassinsphosphatésdans le Maroc occidental. Comptes Rendus de l'Académie des sciences, Paris, 172, 4, 229-231.

[12] Joleaud, L. (1923) Les phosphates du Maroc. Stratigraphieetpétrographie de la région des Ouled Abdoun (Maroc central). Bulletin de la Societe Geologique de France, 172-183.

[13] Depéret, C. and Russo, P. (1925) Les phosphates de melgou (Maroc) etleurfaune de Mosasauriens et de Crocodiliens. Bulletin de la Societe Geologique de France, 4e sér. t. 25, fasc. 4-5, 329-346.

[14] Prévôt, L. (1990) Geochemistry, Petrography, and Genesis of Cretaceous-Eocene Phosphorites. Societe Geologique de France. Memoire, 158-232.

[15] Lucas, J. and Prevot-Lucas, L. (1995) Tethyan Phosphates and Bioproductites. In: Nairn, A.E., et al., Eds., The Ocean Basins and Margins-The Tethys Ocean, Vol. 8, Plenum Press, New York, 367-391.

[16] Grandjean, P., Cappetta, H., Michard, A. and Albarède, F. (1987) The Assessment of REE Patterns and 143Nd/144Nd Ratios in Fish Remains. Earth and Planetary Science Letters, 84, 181-196. http://dx.doi.org/10.1016/0012-821X(87)90084-7

[17] Kolodny, Y. and Raab, M. (1988) Oxygen Isotopes in Phosphatic Fish Remains from Israel: Paleothermometry of Tropical Cretaceous and Tertiary Shelf Waters. Palaeogeography, Palaeoclimatology, Palaeoecology, 64, 59-67. http://dx.doi.org/10.1016/0031-0182(88)90142-3

[18] Salvan, H. (1952) and then 1953. Les Phosphates Marocains: Etude paléontologique des Invertébrés fossiles et étude stratigraphique 19e Congrès Géologie International, Alger, 191.

[19] Yans, J., Amaghzaz, M., Bouya, B., Cappetta, H., Iacumin, P., Kocsis, L., Mouflih, M., Selloum, O., Sen, S., Storme, J.-Y. and Gheerbrant, E. (2014) First Carbon Isotope Chemostratigraphy of the OuledAbdoun Phosphate Basin, Morocco; Implications for Dating and Evolution of Earliest African Placental Mammals. Gondwana Research, 25, 257269. http://dx.doi.org/10.1016/j.gr.2013.04.004

[20] Kocsis, L., Gheerbrant, E., Mouflih, M., Cappetta, H., Yans, J. and Amaghzaz, M. (2014) Comprehensive Stable Isotope Investigation of Marine Biogenic Apatite from the Late Cretaceous-Early Eocene Phosphate Series of Morocco. Palaeogeography, Palaeoclimatology, Palaeoecology, 394, 74-88. http://dx.doi.org/10.1016/j.palaeo.2013.11.002

[21] EL Haddi, H., Benbouziane, A., Jourani E., Amaghzaz, M. and Mouflih, M. (2014) Siliceous Forms of Phosphate Deposits of Cretaceous Age in Oulad Abdoun Basin (Central Morocco). Mineralogy, Geochemistry and Diagenetic Phenomena. Procedia Engineering.

[22] Jourani, Es. (1988) Anatomieséquentielle et géochimie des phosphates de Bouabout (Gisement de Meskala, Maroc): Eléments pour un modèlegénétique. Ph.D. Thesis, Université De Pau et Des Pays De L’Adour, Pau, 205. 
Scientific Research Publishing (SCIRP) is one of the largest Open Access journal publishers. It is currently publishing more than 200 open access, online, peer-reviewed journals covering a wide range of academic disciplines. SCIRP serves the worldwide academic communities and contributes to the progress and application of science with its publication.

Other selected journals from SCIRP are listed as below. Submit your manuscript to us via either submit@scirp.org or Online Submission Portal.
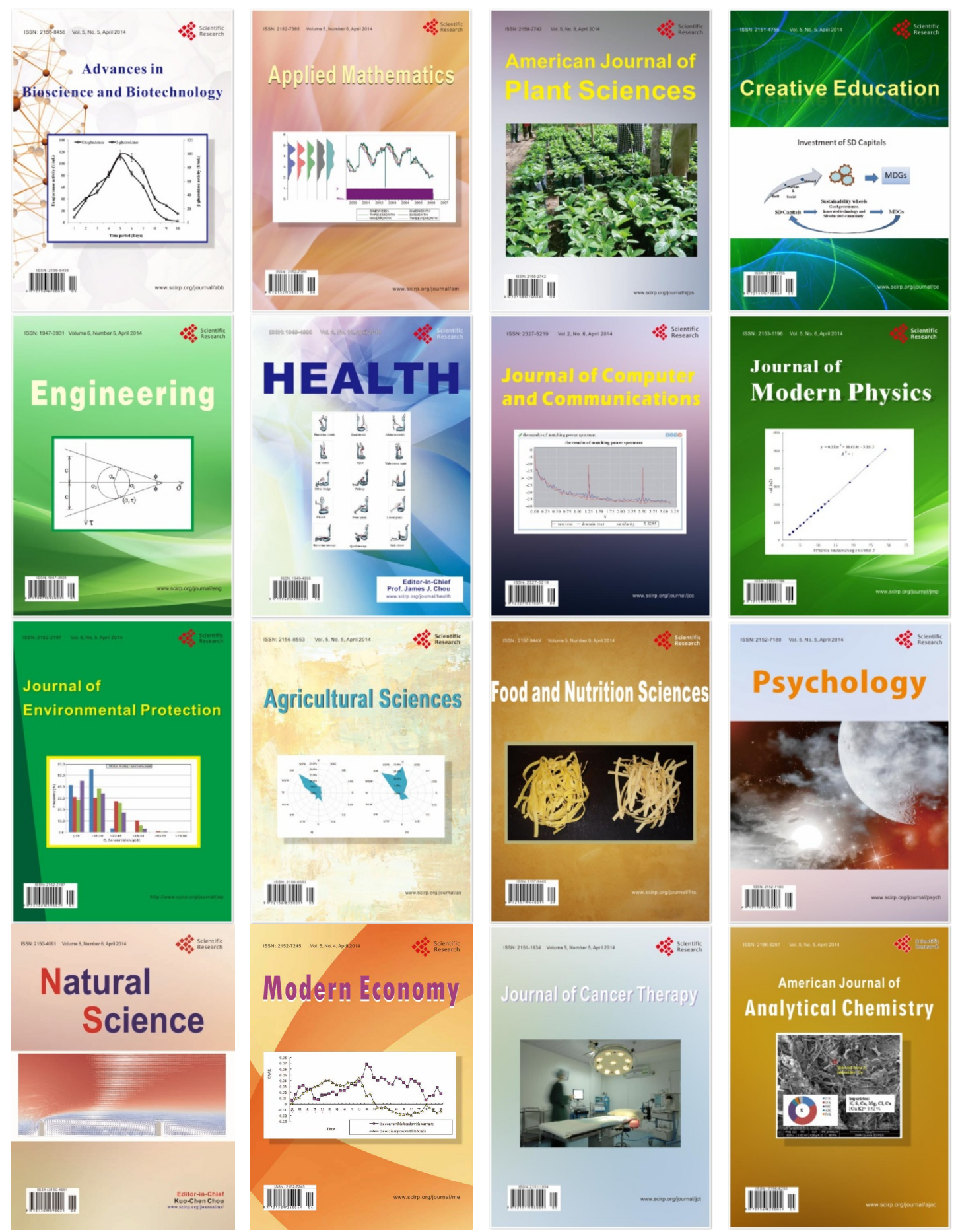